\title{
Optimasi Produksi Bibit Tanaman Kentang (Solanum tuberosum) Kultivar Granola dengan Teknik Fotoautotrofik
}

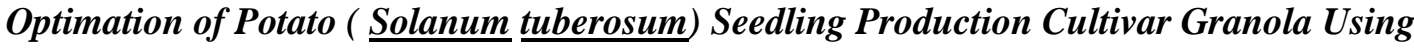 \\ Photoautotrophic System
}

\section{Sonya Putri Rai, Ni Made Armini Wiendi*, dan Krisantini}

\author{
Departemen Agronomi dan Hortikultura, Fakultas Pertanian, Institut Pertanian Bogor (Bogor Agricultural \\ University), Jalan Meranti, Kampus IPB Darmaga, Bogor 16680, Indonesia \\ Telp. \& Faks. 62-251-8629353 e-mail agronipb@indo.net.id \\ *Penulis korespondensi: nmarmini@gmail.com
}

Disetujui 7 Januari 2015/ Publish online 15 januari 2015

ABSTRACT

In vitro plants rarely photosynthesise; their cuticle, vascular tissue between roots and shoots and stomata do not grow and functioning so that the in vitro derived plantlets had low survival in ex vitro conditions. Photoautotrophic micropropagation have potentials to overcome these limitations as it can improve plants'strength and survival when the plantlets were transferred into ex vitro conditions. This research aims to study the growth of potato 'Granola' cultured in vitro with photoautotrophic system to provide good quality potato explants. This research was conducted at the Laboratory of Tissue Culture 2, morphological analysis of stomata was conducted at the Laboratory of Micro Technique, Department of Agronomy and Horticulture, Faculty of Agriculture, Bogor Agricultural University. The research was conducted from November 2014 until April 2015. This research is consisted of two separate experiments. The first experiment used a single node explant, a second trial using shoot explants. The experiment was arranged in a Randomized Blok Design with two factors concentration of sugar and ventilation. Increases in sucrose concentration correlated positively to the growth of Solanum tuberosum plantlets. Interaction of low sugar and additional ventilation increasd the number of stomata and chloroplasts as well as narrowing the diameter of stomata. $45 \%$ plantlets grown on media with the treatment of $25 \mathrm{gL}^{-1}$ sugar with 1 ventilation and $67 \%$ on $25 \mathrm{gL}^{-1}$ sugar with 2 ventilation survived and could be used for seedling production. No plantlets from shoot explant (second experiment) survived in the acclimatization stage.

Keywords : in vitro, photoautotrophic, photosynthesis, potato

\section{ABSTRAK}

Tanaman yang ditumbuhkan dalam kondisi in vitro pada umumnya tidak melakukan fotosintesis, lapisan kutikula dan jaringan pembuluh antara akar dan pucuk tidak berkembang serta stomata belum berfungsi dengan baik sehingga sulit bertahan pada saat aklimatisasi. Teknik fotoautotrofik perlu dikembangkan untuk meningkatkan ketahanan planlet saat dipindahkan ke kondisi ex vitro. Penelitian ini bertujuan mempelajari respon pertumbuhan kentang kultivar Granola yang dikulturkan dengan sistem fotoautotrofik untuk menyediakan bibit kentang yang unggul dan bermutu. Penelitian dilaksanakan di Laboratorium Kultur Jaringan 2, analisis morfologi stomata dilakukan di Laboratorium Mikro Teknik, Departemen Agronomi dan Hortikultura, Fakultas Pertanian, Institut Pertanian Bogor. Penelitian dilakukan dari bulan November 2014 hingga April 2015. Penelitian ini terdiri dari dua percobaan terpisah. Percobaan pertama menggunakan bahan tanam buku tunggal, percobaan kedua menggunakan bahan tanam pucuk. Rancangan percobaan yang digunakan adalah Rancangan Kelompok Lengkap Teracak (RKLT) dua faktor, yaitu konsentrasi gula dan ventilasi. Pada percobaan pertama diperoleh bahwa peningkatan konsentrasi gula nyata meningkatkan jumlah daun dan buku tunas kentang (Solanum tuberosum). Interaksi gula yang rendah dan penambahan ventilasi menyebabkan peningkatan jumlah stomata dan kloroplas serta mengecilnya diameter stomata daun. Sebanyak $45 \%$ planlet yang ditumbuhkan pada media dengan konsentrasi gula $25 \mathrm{gL}^{-1}$ dengan ventilasi 1 serta $67 \%$ planlet dari media gula $25 \mathrm{gL}^{-1}$ dengan ventilasi 2 mampu bertahan selama aklimatisasi dan diduga dapat digunakan untuk produksi bibit. Pada percobaan 2 tidak terdapat planlet yang mampu bertahan pada tahap aklimatisasi.

Kata kunci : fotoautotrofik, fotosintesis, in vitro, kentang 


\section{PENDAHULUAN}

Kentang merupakan salah satu jenis sayuran yang mendapat prioritas untuk dikembangkan di Indonesia. Berdasarkan angka konsumsinya, kentang merupakan bahan pangan keempat di dunia setelah padi, jagung dan gandum. Pada basis bobot segar, kentang memiliki kandungan protein tertinggi dibandingkan dengan umbi-umbian lainnya. Hal ini menunjukkan bahwa kentang memiliki potensi yang baik untuk mendukung program diversifikasi pangan dalam rangka mewujudkan ketahanan pangan berkelanjutan. Produktivitas tanaman kentang di Indonesia relatif masih rendah dan tidak stabil, yaitu berkisar antara 15 sampai 16 ton ha $^{-1}$ (BPS, 2013). Produktivitas kentang maksimum di Australia dan California, Amerika serikat lebih dari 50 ton $\mathrm{ha}^{-1}$ dengan umur panen 120 hari dan kultivar yang ditanam adalah Delaware, Kennebec dan Atlantic (Rukmana, 2007). Indonesia masih mengimpor kentang untuk memenuhi kebutuhan akan bibit, benih dan bahan pangan terutama untuk industri pengolahan.

Rendahnya produksi Indonesia disebabkan belum banyaknya petani penghasil bibit kentang bermutu, sehingga permintaan bibit kentang tidak dapat dipenuhi. Upaya yang dapat dilakukan untuk mengatasi kendala tersebut adalah dengan memanfaatkan bioteknologi yaitu melalui kultur jaringan atau pembiakan mikro kentang. Dengan teknik ini dapat dihasilkan benih berjumlah banyak dalam waktu relatif singkat dan bebas dari penyakit sistemik, terutama virus (Hidayat, 1991).

Masa aklimatisasi merupakan masa kritis bagi kelangsungan hidup tanaman hasil kultur jaringan. Aklimatisasi adalah satu tahapan dalam kultur jaringan yang merupakan proses adaptasi planlet hidup pada kondisi aseptik dan heterotrof lalu dipindah ke kondisi yang tidak aseptik dan harus hidup dalam kondisi autotrof. Tanaman kultur jaringan hampir tidak pernah berfotosistesis, lapisan kutikula tidak berkembang, jaringan pembuluh antara akar dan pucuk tidak berkembang serta stomata yang belum berfungsi dengan baik. Kondisi tersebut menyebabkan tanaman kurang mampu hidup setelah aklimatisasi akibat belum mampu berfotosintesis secara optimal dan beradaptasi pada lingkungan ex vitro.

Menurut Kozai et al. (2005) kultur fotoautotrofik merupakan sistem kultur jaringan tanaman dengan sumber karbon tergantung sepenuhnya pada tanaman in vitro. Dengan sistem ini tanaman ditumbuhkan dalam media kultur tanpa gula agar tanaman terlatih melakukan fotosintesis sedini mungkin. Lingkungan fotoautotrofik harus didukung oleh lingkungan yang menguntungkan untuk eksplan atau planlet, dengan memperhatikan konsentrasi $\mathrm{CO}$, intensitas cahaya dan kelembaban udara di dalam botol kultur. Perbanyakan tanaman dalam lingkungan fotoautotrofik secara in vitro mempunyai berbagai keuntungan, antara lain kemudahan dalam pengawasan lingkungan fisik, meningkatkan multiplikasi, meningkatkan persentase planlet yang hidup, menekan kontaminasi, dapat diterapkan pada wadah kultur yang besar dan dapat mengurangi biaya produksi (bahan-bahan kimia). Pada masa aklimatisasi, planlet hasil perbanyakan dalam keadaan fotoautotrofik lebih mampu bertahan hidup, karena sejak dalam botol kultur tanaman sudah mulai berfotosintesis dan respirasi, sehingga lebih mudah beradaptasi dengan lingkungan ex vitro (Pertamawati, 2010).

Hasil penelitian pada plantlet Limonium latifolium menunjukkan bahwa perbanyakan tanpa menggunakan gula menghasilkan berat kering yang sama, konsentrasi klorofil yang lebih tinggi, laju fotosintesis yang lebih tinggi, sistem perakaran berkembang lebih baik, tunas yang lebih baik dan kontaminasi yang lebih sedikit bila dibandingkan dengan perbanyakan pada media mengandung gula (Xiao dan Kozai, 2006). Varietas Granola banyak dipilih oleh petani karena keunggulannya antara lain berumur pendek, adaptasinya luas, hasil cukup tinggi, bentuk umbi yang bagus dan agak tahan penyakit layu bakteri, meskipun kelemahannya mempunyai kadar air tinggi dan tidak cocok untuk kentang olahan (Purwito dan Wattimena, 2008). Penelitian ini bertujuan mempelajari pertumbuhan tanaman kentang varietas Granola in vitro pada konsentrasi gula rendah dan ventilasi (teknik fotoautotrofik) untuk menghasilkan bibit kentang bermutu.

\section{BAHAN DAN METODE}

Penelitian dilaksanakan di Laboratorium Kultur Jaringan 2, Departemen Agronomi dan Hortikultura, Fakultas Pertanian, Institut Pertanian Bogor. Analisis morfologi stomata dilakukan di Laboratorium Mikro Teknik, Departemen Agronomi dan Hortikultura, Fakultas Pertanian, Institut Pertanian Bogor. Penelitian dilakukan dari bulan November 2014 hingga April 2015. Eksplan yang digunakan adalah stek buku tunggal dan pucuk dari planlet kentang varietas Granola berumur 4 minggu yang dikulturkan di dalam medium MS dengan konsentrasi hara makro dua kali lebih banyak dari konsentrasi yang seharusnya. Bahan yang digunakan adalah paper filter dan micropore $3 \mathrm{M}$ sebagai ventilator, 
kalsium pantotenat $(\mathrm{CaP})$ sebagai hara tambahan serta $\mathrm{HCl}$ dan $\mathrm{KOH}$ untuk pengatur $\mathrm{pH}$. Media yang digunakan adalah media dasar MS (Murashige \& Skoog). Pada tahap ex vitro, bahan yang digunakan adalah media tanam yang mengandung campuran sekam dan tanah dengan perbandingan 1:1 (v/v) serta agrept (bahan aktif $20 \%$ streptomisin sulfat) dan dithane (bahan aktif mancozep $80 \%$ ). Alat yang digunakan terdiri dari laminar air flow cabinet, autoklaf, $\mathrm{pH}$ meter, mikroskop, gelas piala, gelas ukur, erlenmeyer, botol kultur, cawan petri, bunsen, pinset, gunting, pipet, hand sprayer, rak kultur yang dilengkapi dengan lampu 69 watt $\mathrm{m}^{-1}$. Alat yang digunakan pada tahap ex vitro, terdiri dari tray sebagai wadah tanam dan autoklaf untuk sterilisasi media tanam.

Percobaan dalam penelitian ini terdiri dari 2 percobaan terpisah, yaitu percobaan dengan menggunakan bahan tanam buku tunggal dan percobaan menggunakan bahan tanam pucuk. Percobaan ini disusun dengan menggunakan rancangan kelompok lengkap teracak (RKLT) dengan dua faktor. Faktor pertama adalah konsentrasi gula terdiri dari 5 taraf yaitu $5 \mathrm{~g} \mathrm{~L}^{-1}$, $10 \mathrm{~g} \mathrm{~L}^{-1}, 15 \mathrm{~g} \mathrm{~L}^{-1}, 20 \mathrm{~g} \mathrm{~L}^{-1}$ dan $25 \mathrm{~g} \mathrm{~L}^{-1}$. Faktor kedua adalah ventilasi dengan 2 taraf yaitu 1 lubang dan 2 lubang ventilasi. Perlakuan $30 \mathrm{~g} \mathrm{~L}^{-1}$ gula tanpa ventilasi merupakan kontrol. Penanaman eksplan terdiri dari 10 kombinasi perlakuan. Percobaan menggunakan bahan tanam buku tunggal dengan sepuluh ulangan, sedangkan percobaan menggunakan bahan tanam pucuk dengan tiga ulangan. Jumlah satuan percobaan dengan bahan tanam buku tunggal adalah 100 satuan percobaan dan jumlah satuan percobaan dengan bahan tanam pucuk adalah 30 satuan percobaan. Setiap satuan percobaan terdiri dari 5 eksplan sebagai satuan amatan. Data yang diperoleh dianalisis menggunakan sidik ragam atau analysis of varience (ANOVA). Perlakuan yang berpengaruh nyata dilanjutkan dengan uji jarak berganda dari Duncan (DMRT) pada taraf $\alpha$ $5 \%$. Rancangan percobaan yang digunakan adalah Rancangan Kelompok Lengkap Teracak (RKLT) dua faktor yang dikelompokkan berdasarkan waktu penanaman. Perangkat lunak yang digunakan untuk analisis data adalah Micosoft Excel 2010 untuk rekapitulasi data dan seleksi indeks; SAS 9.1.3 untuk uji F dan uji lanjut.

Pelaksanaan percobaan dimulai dengan memperbanyak bahan tanam kentang varietas Granola berupa buku tunggal dan pucuk yang selanjutnya akan digunakan untuk 2 percobaan terpisah. Media tanam dibuat dengan menggunakan larutan stok $\mathrm{A}, \mathrm{B}, \mathrm{C}, \mathrm{D}, \mathrm{E}, \mathrm{F}$, Vitamin dan Myo-inositol yang sesuai dengan 30 komposisi media MS. Jumlah hara makro atau stok $\mathrm{A}, \mathrm{B}, \mathrm{C}$ dan $\mathrm{D}$ dua kali lebih banyak dari komposisi yang sebenarnya. Media MS ditambahkan gula dengan konsentrasi berbeda sesuai dengan perlakuan serta ditambahkan Kalsium pantotenat $(\mathrm{CaP})$ sebanyak $4 \mathrm{mg} \mathrm{L}^{-1}$. Larutan ditambahkan akuades dan ditera menggunakan $\mathrm{pH}$ meter hingga $\mathrm{pH}$ mencapai 6.0 dengan menggunakan $\mathrm{HCl}$ atau $\mathrm{KOH}$. Media yang telah ditera ditambahkan agar dan dipanaskan hingga mendidih. Media dimasukkan ke dalam botol kultur sebanyak $25 \mathrm{ml}$ per botol.

Bahan dan alat disterilisasi dengan menggunakan autoklaf. Ruang tanam yang digunakan adalah laminar air flow cabinet (LAFC) yang disterilisasi dengan disinari lampu ultraviolet selama 1 jam sebelum digunakan dan kemudian dibersihkan dengan cara menyemprotkan alkohol $70 \%$ sebelum digunakan. Setelah penanaman, botol kultur ditutup menggunakan paper filter kemudian dilapisi plastik yang telah diberi ventilasi sesuai perlakuan. Lubang ventilasi berdiameter $7 \mathrm{~mm}$ dan ditutup dengan menggunakan micropore 0.2 $\mu \mathrm{m}$.

Tahap ex vitro atau aklimatisasi dilakukan pada 6 minggu setelah kultur in vitro. Media aklimatisasi menggunakan campuran sekam dan kompos dengan perbandingan 1:1 (v/v) untuk semua jenis perlakuan serta menggunakan wadah tray. Campuran media disterilisasi dengan cara dipanaskan menggunakan autoklaf dengan suhu $121{ }^{0} \mathrm{C}$ selama 25 menit. Media yang sudah disterilisasi dimasukkan ke dalam tray. Bibit dikeluarkan dari botol menggunakan pinset satu persatu lalu dicuci hingga bersih dari media agar dengan air steril. Akar-akar yang terlalu panjang dipotong dengan gunting kemudian direndam dengan larutan streptomosin sulfat $20 \%$ dan mancozep $80 \%$. Bibit ditanam pada tray yang sudah diberikan media dan diletakkan pada rak kultur yang dilengkapi dengan lampu 69 watt $\mathrm{m}^{-1}$. Penyiraman dilakukan 2-3 kali sehari dengan menggunakan air steril. Terdapat tiga ulangan yang diaklimatisasi untuk setiap perlakuan pada percobaan 1 dan dua ulangan pada percobaan 2

Pengamatan yang dilakukan meliputi pengamatan kuantitatif pada tahap in vitro dan ex vitro serta uji morfologi stomata pada tahap ex vitro. Peubah yang diamati pada tahap in vitro adalah jumlah daun, jumlah buku serta waktu munculnya akar yang dihitung saat eksplan berumur 1-6 MST (minggu setelah tanam). Persentase kontaminasi dan persentase eksplan hidup diamati setiap hari selama 6 minggu. Pengamatan pada tahap ex vitro meliputi jumlah daun, jumlah buku dan persentase planlet hidup

Sonya Putri R, Ni Made Armini W dan Krisantini 
yang diamati pada 0, 5 dan 7 HSA (hari setelah aklimatisasi). Uji morfologi stomata dilakukan pada daun dari buku pertama untuk setiap pengujian. Analisis morfologi stomata dan kloroplas dimulai dengan mengambil daun bagian epidermis bawah tanaman dan meletakkannya pada selotip. Tahap selanjutnya dilakukan pengerokan pada bagian atas daun menggunakan silet sampai hanya tersisa lapisan tipis di bawah daun, lalu diamati di bawah mikroskop. Foto dibuat di bawah mikroskop dengan perbesaran $10 x 40$. Stomata diamati sebanyak tiga ulangan. Jumlah stomata diamati melalui tiga bidang pandang. Diameter stomata diukur dari sisi terlebar dengan jumlah sebanyak tiga stomata untuk tiga ulangan pada setiap perlakuan. Jumlah kloroplas dihitung dari tiga stomata untuk tiga ulangan pada setiap perlakuan.

\section{HASIL DAN PEMBAHASAN}

\section{Kondisi Umum Kultur In Vitro}

Secara umum pertumbuhan tanaman berlangsung baik walaupun terjadi kontaminasi pada media dengan perlakuan konsentrasi gula $20 \mathrm{~g} \mathrm{~L}^{-1}$ dengan ventilasi 1 serta $10 \mathrm{~g} \mathrm{~L}^{-1}$ dengan ventilasi 2 masing-masing pada 2 MST dan 3 MST (Percobaan 1). Umur 4 MST terjadi penyusutan media yang menyebabkan kekeringan pada beberapa tanaman di dalam botol kultur. Hal ini menyebabkan dilakukan pemindahan media pada perlakuan-perlakuan yang mengalami susut media. Kondisi ini diperkirakan karena air pada media menguap akibat adanya ventilasi yang disinari langsung oleh cahaya lampu yang terjadi setelah 4 MST.

\section{Percobaan 1. Perbanyakan Bibit Kentang (Solanum Tuberosum) Kultivar Granola Melalui Teknik Fotoautotrofik In Vitro dengan Bahan Tanam Buku Tunggal}

\section{Pertumbuhan Eksplan In Vitro}

Pemberian ventilasi meningkatkan jumlah daun dan jumlah buku tetapi tidak mempengaruhi persentase kontaminasi dan persentase eksplan hidup (Tabel 1). Perlakuan ventilasi menyebabkan persentase kontaminasi yang tinggi pada media karena terdapat pertukaran udara saat inkubasi kultur, namun rendahnya konsentrasi gula juga dapat menurunkan pertumbuhan organisme kontaminan dalam wadah sehingga kematian eksplan akibat serangan organisme kontaminan juga dapat ditekan (Xiao dan Kozai, 2006).

Tabel 1. Pengaruh konsentrasi gula dan ventilasi terhadap pertumbuhan kentang varietas Granola secara fotoautotrofik

\begin{tabular}{cccc}
\hline $\begin{array}{c}\text { Konsentrasi } \\
\text { gula }\left(\mathrm{g} \mathrm{L}^{-1}\right)\end{array}$ & Jumlah daun & Jumlah buku & Persentase eksplan hidup \\
\hline 5 & $3.44 \mathrm{~d}$ & $1.38 \mathrm{~d}$ & 97.50 \\
10 & $6.35 \mathrm{c}$ & $3.10 \mathrm{c}$ & 96.33 \\
15 & $7.95 \mathrm{~b}$ & $4.12 \mathrm{~b}$ & 97.22 \\
20 & $8.77 \mathrm{~b}$ & $4.67 \mathrm{a}$ & 97.78 \\
25 & $9.89 \mathrm{a}$ & $5.20 \mathrm{a}$ & 97.46 \\
Kontrol & $8.80 \mathrm{~b}$ & $4.70 \mathrm{a}$ & 99.67 \\
Uji F & $* *$ & $* *$ & tn \\
\hline Ventilasi & Jumlah daun & Jumlah buku & Persentase eksplan hidup \\
\hline 1 & $6.93 \mathrm{~b}$ & $3.50 \mathrm{~b}$ & 95.10 \\
2 & $7.59 \mathrm{~b}$ & $3.86 \mathrm{~b}$ & 95.60 \\
Kontrol & $8.80 \mathrm{a}$ & $4.70 \mathrm{a}$ & 99.67 \\
Uji F & $*$ & $*$ & tn \\
KK $(\%)$ & 17.89 & 19.72 & 810.01 \\
\hline
\end{tabular}

Keterangan: tn : tidak berbeda nyata pada uji $\mathrm{F}$ taraf $\alpha 5 \%$, * berbeda nyata pada uji $\mathrm{F}$ taraf $\alpha 5 \%, * *$ : berbeda sangat nyata pada uji $\mathrm{F}$ taraf $\alpha 1 \%$ Angka-angka yang diikuti huruf sama pada kolom yang sama tidak berbeda nyata pada uji DMRT taraf $\alpha$ $5 \%$

Peningkatan konsentrasi gula meningkatkan jumlah daun dan jumlah buku namun tidak mempengaruhi persentase kontaminasi dan persentasi eksplan hidup. Tabel 1 menunjukkan bahwa perlakuan $25 \mathrm{~g} \mathrm{~L}^{-1}$ menyebabkan respon tertinggi pada peubah jumlah daun. Eksplan yang dikulturkan pada media dengan konsentrasi gula $20 \mathrm{~g} \mathrm{~L}^{-1}$ memberikan respon yang tidak berbeda dengan $15 \mathrm{~g} \mathrm{~L}^{-1}$ dan kontrol. Media dengan perlakuan konsentrasi gula $5 \quad \mathrm{~g}^{-1}$ dan $10 \mathrm{~g}^{-1}$ menyebabkan respon jumlah daun paling sedikit. Menurut Kubota (2002) pada mikropropagasi fotoautotrofik akan terjadi peningkatan pertumbuhan pada tanaman bila dibandingkan 
dengan mikropropagasi konvensional. Pada percobaan ini, jumlah daun dan buku pada mikropropagasi fotoautotrofik lebih baik dibandingkan dengan mikropropagasi konvensional hanya pada perlakuan gula $20 \mathrm{~g} \mathrm{~L}^{-1}$ dan $25 \mathrm{~g} \mathrm{~L}^{-1}$.

Semakin banyak karbon dioksida $\left(\mathrm{CO}_{2}\right)$ di udara, semakin banyak jumlah bahan yang dapat digunakan tumbuhan untuk melangsungkan fotosintesis. Jika kadar $\mathrm{CO}_{2}$ dalam sel rendah maka fotosintesis akan menurun. Kondisi di dalam wadah kultur pada perbanyakan konvensional memiliki konsentrasi $\mathrm{CO}_{2}$ yang rendah selama fotoperiodisitas sehingga proses fotosintesis hampir tidak terjadi (Kubota 2002). Pemberian ventilasi memungkinkan terjadinya pertukaran udara pada botol kultur. Pertumbuhan daun dan buku pada perlakuan dua lubang ventilasi lebih baik dibandingkan satu lubang ventilasi, namun hasil keduanya tidak berbeda nyata. Hal ini mengindikasikan bahwa jumlah ventilasi berkolerasi positif terhadap pertumbuhan tanaman kentang pada mikropropagasi fotoautotrofik.

Tabel 2. Waktu munculnya akar pada tanaman kentang varietas Granola

\begin{tabular}{ccc}
\hline $\begin{array}{c}\text { Ponsentrasi gula } \\
\left(\mathrm{g} \mathrm{L}^{-1}\right)\end{array}$ & $\begin{array}{c}\text { Jumlah } \\
\text { ventilasi }\end{array}$ & $\begin{array}{c}\text { Waktu munculnya } \\
\text { akar (MST) }\end{array}$ \\
\hline 5 & 1 & 3 \\
& 2 & 3 \\
10 & 1 & 2 \\
& 2 & 3 \\
15 & 1 & 3 \\
& 2 & 3 \\
20 & 1 & 3 \\
& 2 & 3 \\
25 & 1 & 2 \\
& 2 & 3 \\
30 & 0 & 3 \\
\hline
\end{tabular}

Tunas pada kontrol menghasilkan jumlah daun tertinggi saat 1 MST dibandingkan dengan perlakuan lain, namun pada 2 MST tunas pada perlakuan konsentrasi gula $25 \mathrm{~g} \mathrm{~L}^{-1}$ dengan ventilasi 1 mempunyai jumlah daun yang sama dengan kontrol. Pada 2, 3 dan 4 MST jumlah daun tertinggi dihasilkan oleh tunas pada perlakuan konsentrasi gula $25 \mathrm{~g} \mathrm{~L}^{-1}$ dengan ventilasi 1 , sedangkan pada 5 dan 6 MST terlihat pada perlakuan konsentrasi gula $25 \mathrm{~g} \mathrm{~L}^{-1}$ dengan ventilasi 2. Hal ini menunjukkan bahwa hanya perlakuan dengan konsentrasi gula $25 \mathrm{~g} \mathrm{~L}^{-1}$ dengan ventilasi 1 serta konsentrasi gula $25 \mathrm{~g} \mathrm{~L}^{-1}$ dengan ventilasi 2 yang dapat menyebabkan respon pertumbuhan lebih baik dibandingkan dengan kontrol (data tidak disajikan).
Percobaan ini seluruh tunas menghasilkan akar antara 2-3 MST (Tabel 2). Hal ini menunjukkan bahwa interaksi gula dan ventilasi tidak mempengaruhi munculnya akar.

\section{Morfologi Stomata}

Kombinasi perlakuan konsentrasi gula dan jumlah ventilasi nyata meningkatkan jumlah stomata dan kerapatan stomata serta mengakibatkan menyempitnya diameter stomata, namun tidak meningkatkan jumlah kloroplas (Tabel 3). Mikropropagasi fotoautotrofik memiliki kelebihan dibanding kultur jaringan konvensional, yaitu peningkatan fotosintesis yang dilakukan oleh tanaman dan dilihat melalui kerapatan stomata yang tinggi, diameter stomata mengecil dan memiliki kemampuan menyimpan air saat dipindahkan ke kondisi ex vitro (Kubota 2002).

Tabel 3. Rekapitulasi hasil uji $\mathrm{F}$ pengaruh kombinasi konsentrasi gula dengan jumlah ventilasi terhadap morfologi stomata tanaman kentang varietas Granola

\begin{tabular}{|c|c|c|c|c|c|}
\hline Peubah & \multicolumn{5}{|c|}{ GulaVentilasi UlanganInteraksiKK $(\%)$} \\
\hline Jumlah stomata & $* *$ & $* *$ & tn & $* *$ & 2.43 \\
\hline $\begin{array}{c}\text { Kerapatan } \\
\text { stomata }\end{array}$ & ** & $* *$ & tn & $* *$ & 4.25 \\
\hline $\begin{array}{c}\text { Diameter } \\
\text { stomata } \\
\text { Jumlah }\end{array}$ & ** & $*$ & $\operatorname{tn}$ & $*$ & 6.47 \\
\hline kloroplas & $* *$ & $* *$ & tn & tn & 3.62 \\
\hline
\end{tabular}

Jumlah stomata yang lebih sedikit per satuan luas daun menunjukkan bahwa tunas kentang pada perlakuan pengurangan konsentrasi gula dan pemberian ventilasi memiliki stomata yang lebih besar. Ukuran stomata yang besar menyebabkan jumlah stomata lebih sedikit tiap luas bidang pandang. Adanya stomata pada daun memungkinkan terjadinya pertukaran gas. Jumlah stomata yang sedikit pada tanaman dapat menjadi indikator bahwa tanaman mengalami laju fotosintesis yang rendah. Pada mikropropagasi in vitro tanaman hampir tidak melakukan proses fotosintesis karena gula sebagai sumber energi utama bagi eksplan telah disediakan (Kubota, 2002). Pengurangan konsentrasi gula dapat memicu terjadinya fotosintesis yang ditandai dengan banyaknya jumlah stomata (Tabel 4).

Sonya Putri R, Ni Made Armini W dan Krisantini 
Tabel 4. Pengaruh interaksi gula dan ventilasi terhadap morfologi stomata tanaman kentang varietas Granola

\begin{tabular}{ccllcc}
\hline $\begin{array}{c}\text { Konsentrasi gula } \\
\left(\mathrm{g} \mathrm{L}^{-1}\right)\end{array}$ & $\begin{array}{c}\text { Jumlah } \\
\text { ventilasi }\end{array}$ & $\begin{array}{c}\text { Rataan jumlah } \\
\text { stomata }\end{array}$ & $\begin{array}{c}\text { Kerapatan } \\
\text { stomata/mm } / \mathrm{mm}^{2}\end{array}$ & $\begin{array}{c}\text { Rataan diameter } \\
\text { stomata }(\mathrm{mm})\end{array}$ & $\begin{array}{c}\text { Rataan jumlah } \\
\text { kloroplas }\end{array}$ \\
\hline 5 & 1 & $37.0 \mathrm{a}$ & $188.5 \mathrm{a}$ & $21555.4 \mathrm{~d}$ & 23.3 \\
& 2 & $38.0 \mathrm{a}$ & $193.6 \mathrm{a}$ & $19469.1 \mathrm{~d}$ & 25.0 \\
10 & 1 & $35.7 \mathrm{a}$ & $181.7 \mathrm{a}$ & $21551.7 \mathrm{~d}$ & 22.0 \\
& 2 & $37.0 \mathrm{ab}$ & $188.5 \mathrm{ab}$ & $19592.5 \mathrm{~d}$ & 24.0 \\
15 & 1 & $34.0 \mathrm{~b}$ & $173.3 \mathrm{~b}$ & $23271.0 \mathrm{c}$ & 21.3 \\
& 2 & $37.3 \mathrm{ab}$ & $190.2 \mathrm{ab}$ & $22707.5 \mathrm{c}$ & 23.3 \\
20 & 1 & $33.3 \mathrm{~b}$ & $169.9 \mathrm{~b}$ & $22595.5 \mathrm{~cd}$ & 22.0 \\
& 2 & $37.3 \mathrm{ab}$ & $190.2 \mathrm{ab}$ & $23599.2 \mathrm{bc}$ & 19.3 \\
& 1 & $28.3 \mathrm{c}$ & $144.4 \mathrm{c}$ & $25214.9 \mathrm{~b}$ & 21.3 \\
\end{tabular}

Keterangan: Angka-angka yang diikuti huruf sama pada kolom yang sama tidak berbeda nyata pada uji DMRT taraf $\alpha$ 5\%

Ventilasi 2 menyebabkan daun pada tunas menghasilkan jumlah stomata yang lebih banyak dibandingkan dengan ventilasi 1 pada semua perlakuan. Daun dari tunas yang ditumbuhkan pada media dengan perlakuan 5 $\mathrm{gL}^{-1}$ dengan ventilasi 1 menghasilkan kerapatan stomata tertinggi dan tidak berbeda dengan perlakuan konsentrasi gula $5 \mathrm{~g} \mathrm{~L}^{-1}$ dengan ventilasi $2,10 \mathrm{~g} \mathrm{~L}^{-1}$ dengan ventilasi $1,10 \mathrm{~g} \mathrm{~L}^{-1}$ dengan ventilasi $2,15 \mathrm{~g} \mathrm{~L}^{-1}$ dengan ventilasi 2 serta $20 \mathrm{~g} \mathrm{~L}^{-1}$ dengan ventilasi 2. Media dengan perlakuan ventilasi 1 menyebabkan daun menghasilkan jumlah stomata yang tinggi jika dikombinasikan dengan gula yang rendah $\left(5 \mathrm{~g} \mathrm{~L}^{-}\right.$ ${ }^{1}$ dengan ventilasi 1 serta gula $10 \mathrm{~g} \mathrm{~L}^{-1}$ dengan ventilasi 1). Hal ini menunjukkan bahwa banyaknya pertukaran udara melalui ventilasi 2 dan rendahnya konsentrasi gula meningkatkan pembentukan stomata.

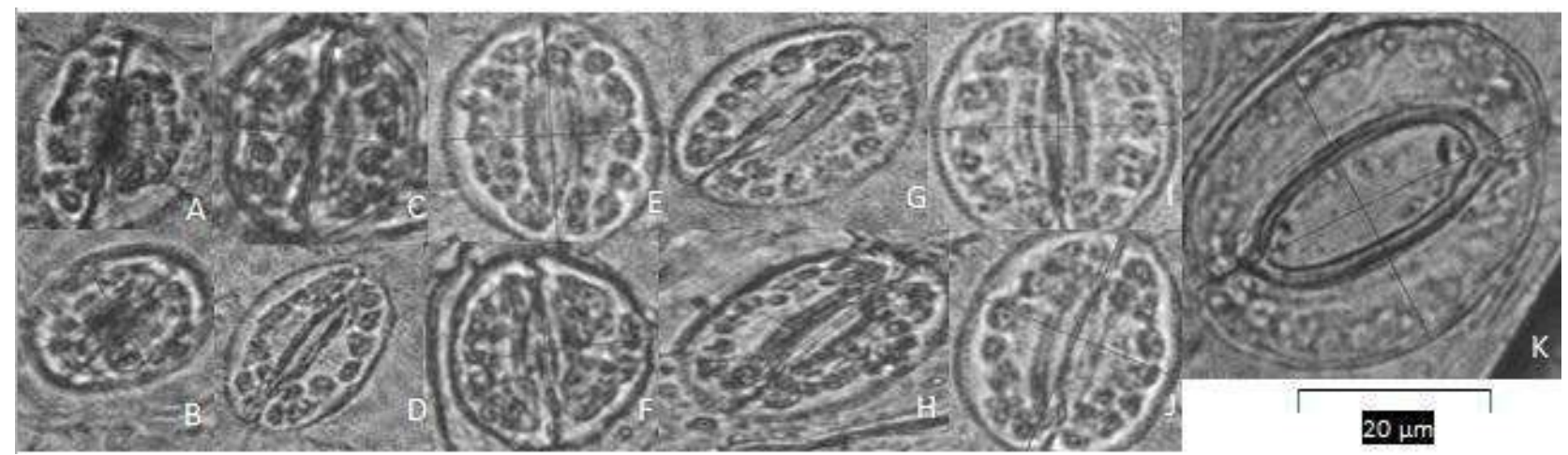

Gambar 1. Keragaan stomata tanaman kentang varietas Granola dengan teknik fotoautotrofik pada perlakuan konsentrasi gula $5 \mathrm{gL}^{-1}(\mathrm{~A}, \mathrm{~B}) ; 10 \mathrm{gL}^{-1}(\mathrm{C}, \mathrm{D}) ; 15 \mathrm{gL}^{-1}(\mathrm{E}, \mathrm{F}) ; 20 \mathrm{gL}^{-1}(\mathrm{G}, \mathrm{H}) ; 25 \mathrm{gL}^{-1}$ (I,J) dengan ventilasi 1(A,C,E,G,I); ventilasi 2 (B,D,F,H,J); kontrol (K)

Tanaman kentang merupakan tanaman C3 yang akan melakukan penutupan stomata ketika berada dalam kondisi pencahayaan untuk mengurangi proses transpirasi (Campbell, 2004). Pengambilan sampel untuk pengamatan morfologi stomata dilakukan pada kondisi pencahayaan. Pada Tabel 5 perlakuan konsentrasi gula $5 \mathrm{~g} \mathrm{~L}^{-1}$ dengan ventilasi 1 (Gambar 1A) menyebabkan daun pada tunas menghasilkan diameter terkecil dan tidak berbeda pada perlakuan gula $5 \mathrm{~g} \mathrm{~L}^{-1}$ dengan ventilasi 2 (B), gula $10 \mathrm{~g} \mathrm{~L}^{-1}$ dengan ventilasi 1 (C) serta gula $10 \mathrm{~g} \mathrm{~L}^{-1}$ dengan ventilasi

Optimasi Produksi Bibit.....
2 (D). Diameter terbesar dihasilkan oleh daun dari tunas pada perlakuan gula $25 \mathrm{~g} \mathrm{~L}^{-1}$ dengan ventilasi 2 (J) yang tidak berbeda dengan perlakuan gula $20 \mathrm{~g} \mathrm{~L}^{-1}$ dengan ventilasi $2(\mathrm{H})$ serta gula $25 \mathrm{~g} \mathrm{~L}^{-1}$ dengan ventilasi 1 (I). Diameter stomata pada daun dengan perlakuan pengurangan konsentrasi gula dan pemberian ventilasi memiliki diameter stomata lebih kecil dibandingkan dengan kontrol (K). Hal ini mengindikasikan bahwa semakin kecil konsentrasi gula dengan pemberian ventilasi akan menyebabkan sel penjaga pada stomata menjadi lebih baik dibandingkan dengan sistem 
konvensional.

Stomata diapit oleh sepasang sel penjaga. Sel penjaga mengontrol diameter stomata dengan cara menyempitkan atau melebarkan celah diantara kedua sel tersebut. Ketika sel penjaga mengambil air melalui osmosis, sel penjaga akan membengkak. Ketika sel kehilangan air, sel penjaga menjadi lembek serta mengkerut, sel-sel tersebut akan mengecil secara bersamaan kemudian menutup ruangan diantaranya (Campbell, 2004). Menurut Kozai et al. (2005) sel penjaga pada tanaman in vitro tidak dapat berfungsi secara normal sehingga stomata akan membuka secara terus menerus dan memicu terjadinya transpirasi yang berlebihan saat dikeluarkan dari botol kultur dan menyebabkan tanaman mati. Pengurangan konsentrasi gula dan pemberian ventilasi pada tanaman in vitro memicu terjadinya proses fotosintesis sehingga diameter stomata mengkerut saat kehilangan air.

Organ utama tumbuhan tempat berlangsungnya fotosintesis adalah daun. Tumbuhan menangkap cahaya menggunakan pigmen yang disebut klorofil yang memberi warna hijau pada tumbuhan. Klorofil terdapat dalam organel yang disebut kloroplas, dimana fotosintesis berlangsung tepatnya pada bagian stroma (Campbell 2004). Tabel 4 menunjukkan bahwa setiap perlakuan menyebabkan jumlah kloroplas pada stomata hampir sama dan lebih tinggi jika dibandingkan dengan kontrol. Hal ini mengindikasikan bahwa pengurangan konsentrasi gula dan penambahan ventilasi dapat mendorong tanaman in vitro untuk melakukan penangkapan cahaya yang lebih baik, hal ini diduga melalui banyaknya kloroplas.

\section{Percobaan II. Perbanyakan Bibit Kentang (Solanum Tuberosum) Kultivar Granola Melalui Teknik Fotoautotrofik In Vitro dengan Bahan Tanam Pucuk}

\section{Pertumbuhan Eksplan In Vitro}

Pengurangan konsentrasi gula dan ventilasi meningkatkan jumlah daun dan jumlah buku namun tidak mempengaruhi persentase kontaminasi dan persentase eksplan hidup.

Tabel 5. Pengaruh konsentrasi gula dan ventilasi terhadap pertumbuhan kentang varietas Granola secara fotoautotrofik

\begin{tabular}{clll}
\hline $\begin{array}{c}\text { Konsentrasi } \\
\text { gula }\left(\mathrm{g} \mathrm{L}^{-1}\right)\end{array}$ & Jumlah daun & Jumlah buku & Persentase eksplan hidup \\
\hline 5 & $3.38 \mathrm{de}$ & $1.43 \mathrm{~d}$ & 95.50 \\
10 & $3.80 \mathrm{~cd}$ & $1.71 \mathrm{~cd}$ & 97.22 \\
15 & $4.73 \mathrm{c}$ & $2.26 \mathrm{c}$ & 82.77 \\
20 & $4.31 \mathrm{~cd}$ & $2.11 \mathrm{~cd}$ & 78.35 \\
25 & $6.72 \mathrm{~b}$ & $3.28 \mathrm{~b}$ & 94.45 \\
Kontrol & $9.47 \mathrm{a}$ & $4.90 \mathrm{a}$ & 94.43 \\
Uji F & $* *$ & $* *$ & tn \\
\hline Ventilasi & Jumlah daun & Jumlah buku & Persentase eksplan hidup \\
\hline 1 & $5.00 \mathrm{~b}$ & $2.40 \mathrm{~b}$ & 92.23 \\
2 & $4.18 \mathrm{c}$ & $1.93 \mathrm{~b}$ & 86.89 \\
Kontrol & $9.46 \mathrm{a}$ & $4.90 \mathrm{a}$ & 94.43 \\
Uji F & $*$ & $*$ & th \\
KK $(\%)$ & 12.5 & 20.8 & 19.4 \\
\hline
\end{tabular}

Keterangan: tn : tidak berbeda nyata pada uji $\mathrm{F}$ taraf $\alpha$ 5\%, * : berbeda nyata pada uji $\mathrm{F}$ taraf $\alpha 5 \%$, **: berbeda sangat nyata pada uji F taraf $\alpha 1 \%$ Angka-angka yang diikuti huruf sama pada kolom yang sama tidak berbeda nyata pada uji DMRT taraf $\alpha$ $5 \%$

Tabel 5 menunjukkan bahwa jumlah daun dan buku pada tunas yang ditumbuhkan pada media dengan konsentrasi gula $25 \mathrm{~g} \mathrm{~L} \mathrm{~L}^{-1}$ memberikan respon yang lebih tinggi dibandingkan pada perlakuan gula $5 \mathrm{~g} \mathrm{~L}^{-1}, 10 \mathrm{~g} \mathrm{~L}$ 1, $15 \mathrm{~g} \mathrm{~L}^{-1}$ dan $20 \mathrm{~g} \mathrm{~L}^{-1}$. Jumlah daun dan buku yang dibentuk eksplan pada kontrol (gula $30 \mathrm{~g} \mathrm{~L}$ $\left.{ }^{1}\right)$ lebih tinggi dibandingkan dengan perlakuan lain, sementara itu konsentrasi gula $5 \mathrm{~g} \mathrm{~L}^{-1}$ menghasilkan jumlah daun dan buku paling sedikit dan tidak berbeda nyata dengan pemberian gula $10 \quad \mathrm{~g} \quad \mathrm{~L}^{-1}$ dan $20 \mathrm{~g} \quad \mathrm{~L}^{-1}$. Hal ini mengindikasikan bahwa tingginya konsentrasi gula berkolerasi positif terhadap pertumbuhan tanaman kentang.

Tabel 5 menunjukkan bahwa pemberian ventilasi pada botol kultur nyata meningkatkan jumlah daun dan buku. Tunas pada kontrol membentuk daun dan buku lebih banyak dibandingkan botol kultur dengan ventilasi. Satu ventilasi membentuk jumlah daun dan buku lebih tinggi dibandingkan dengan dua ventilasi. Pada percobaan ini tidak terdapat kultur yang 
terkontaminasi. Hal ini mungkin disebabkan oleh pengurangan konsentrasi gula yang dapat menekan tumbuhnya organisme kontaminan (Xiao dan Kozai 2006).

Percobaan ini menunjukkan jumlah daun dan buku tertinggi sampai dengan 6 MST dihasilkan oleh tunas kentang pada kontrol. Perlakuan konsentrasi gula $25 \mathrm{~g} \mathrm{~L} \mathrm{~L}^{-1}$ dengan ventilasi 2 menyebabkan pembentukan daun dan buku pada tunas lebih baik dibandingkan dengan perlakuan lainnya (data tidak disajikan). Hal ini menunjukkan bahwa semakin tinggi konsentrasi gula, semakin tinggi peningkatan pertumbuhannya. Hasil ini tidak sesuai dengan Kozai et al. (2005) yang menyatakan bahwa mikropropagasi fotoautotrofik akan menghasilkan pertumbuhan yang lebih baik dibandingkan dengan sistem konvensional. Hal ini mungkin disebabkan oleh kurangnya jumlah ventilasi yang terdapat pada botol kultur sehingga mengurangi pertukaran gas-gas penting dalam proses fotosintesis untuk menghasilkan pertumbuhan yang baik.

Tidak semua tunas mampu membentuk akar (Tabel 6). Pengurangan konsentrasi gula menyebabkan tunas tidak mampu membentuk akar. Pada kontrol, akar pada tunas muncul saat 23 MST sedangkan pada perlakuan konsentrasi gula $15 \mathrm{~g} \mathrm{~L}^{-1}$ dengan ventilasi 1 , gula $15 \mathrm{~g} \mathrm{~L}^{-1}$ dengan ventilasi 2 , gula $20 \mathrm{~g} \mathrm{~L}^{-1}$ dengan ventilasi 1 , gula $20 \mathrm{~g} \mathrm{~L}^{-1}$ dengan ventilasi 2 , gula $25 \mathrm{~g} \mathrm{~L}^{-1}$ dengan ventilasi 1 serta gula $25 \mathrm{~g} \mathrm{~L}^{-1}$ dengan ventilasi 2 akar pada tunas muncul saat 4 MST.

Tabel 6. Waktu munculnya akar aada tanaman kentang varietas Granola

\begin{tabular}{|c|c|c|}
\hline \multicolumn{2}{|c|}{ Perlakuan } & \multirow{2}{*}{$\begin{array}{l}\text { Waktu munculnya } \\
\text { akar (MST) }\end{array}$} \\
\hline $\begin{array}{c}\text { Konsentrasi gula } \\
\left(\mathrm{g} \mathrm{L}^{-1}\right)\end{array}$ & $\begin{array}{c}\text { Jumlah } \\
\text { ventilasi }\end{array}$ & \\
\hline \multirow[t]{2}{*}{5} & 1 & - \\
\hline & 2 & - \\
\hline \multirow[t]{2}{*}{10} & 1 & - \\
\hline & 2 & - \\
\hline \multirow[t]{2}{*}{15} & 1 & - \\
\hline & 2 & 4 \\
\hline \multirow[t]{2}{*}{20} & 1 & 4 \\
\hline & 2 & 4 \\
\hline \multirow[t]{2}{*}{25} & 1 & 4 \\
\hline & 2 & 4 \\
\hline 30 & 0 & 2.93 \\
\hline
\end{tabular}

\section{Morfologi Stomata}

Interaksi perlakuan konsentrasi gula dan jumlah ventilasi nyata meningkatkan jumlah stomata, kerapatan stomata dan jumlah kloroplas pada daun serta berpengaruh nyata terhadap menyempitnya diameter stomata (Tabel 7).

Tabel 7. Rekapitulasi hasil uji F pengaruh kombinasi konsentrasi gula dengan jumlah ventilasi terhadap morfologi stomata tanaman kentang varietas Granola

\begin{tabular}{cccccc}
\hline Peubah & Gula & Ventilasi & Ulangan & Interaksi & KK $(\%)$ \\
\hline Jumlah stomata & $* *$ & tn & tn & $* *$ & 2.54 \\
Kerapatan stomata & $* *$ & tn & tn & $* *$ & 2.54 \\
Diameter stomata & $* *$ & $* *$ & tn & $*$ & 3.48 \\
Jumlah kloroplas & $* *$ & $* *$ & tn & $* *$ & 2.50 \\
\hline
\end{tabular}

Keterangan: tn : tidak berbeda nyata pada uji $\mathrm{F}$ taraf $\alpha 5 \%, *$ : berbeda nyata pada uji $\mathrm{F}$ taraf $\alpha 5 \%$, ** : berbeda sangat nyata pada uji $\mathrm{F}$ taraf $\alpha 1 \%$

Perlakuan konsentrasi gula $5 \mathrm{~g} \mathrm{~L}^{-1}$ dengan ventilasi 1 dan 2 menyebabkan kerapatan stomata tertinggi pada daun dalam percobaan ini. Perlakuan konsentrasi gula $10 \mathrm{~g} \mathrm{~L}^{-1}$ dengan ventilasi 1 , gula $10 \mathrm{~g} \mathrm{~L}^{-1}$ dengan ventilasi 2 , gula $15 \mathrm{~g} \mathrm{~L}^{-1}$ dengan ventilasi 1 serta gula $15 \mathrm{~g} \mathrm{~L}-1$ dengan ventilasi 2 tidak menyebabkan perbedaan kerapatan stomata pada daun (Tabel 8). Perlakuan konsentrasi gula $25 \mathrm{~g} \mathrm{~L}^{-1}$ dengan ventilasi 2 menyebabkan kerapatan terkecil pada daun dalam percobaan ini. Hal ini mengindikasikan bahwa kecilnya konsentrasi gula dan banyaknya jumlah ventilasi meningkatkan jumlah dan kerapatan stomata daun.

Stomata akan menutup jika selisih kandungan uap air di udara dan dalam ruang antar sel melebihi kritis (Campbell 2004). Karena seluruh kebutuhan nutrisinya disediakan, tanaman in vitro hampir tidak melakukan fotosintesis dan sel yang mengatur mekanisme membuka serta menutupnya stomata pada tanaman in vitro tidak terbiasa untuk bekerja sesuai dengan fungsinya sehingga stomata akan membuka meskipun berada pada kondisi kritis air (Kozai, 1992). 
Tabel 8. Pengaruh interaksi gula dan ventilasi terhadap morfologi stomata tanaman kentang varietas Granola

\begin{tabular}{|c|c|c|c|c|c|}
\hline \multicolumn{2}{|c|}{ Perlakuan } & \multirow[b]{2}{*}{$\begin{array}{l}\text { Rataan jumlah } \\
\text { stomata }\end{array}$} & \multirow[b]{2}{*}{$\begin{array}{c}\text { Kerapatan } \\
\text { stomata/mm } \mathrm{mm}^{2}\end{array}$} & \multirow[b]{2}{*}{$\begin{array}{l}\text { Rataan diameter } \\
\text { stomata }(\mathrm{nm})\end{array}$} & \multirow[b]{2}{*}{$\begin{array}{c}\text { Rataan jumlah } \\
\text { kloroplas }\end{array}$} \\
\hline $\begin{array}{c}\text { Konsentrasi gula } \\
\left(\mathrm{g} \mathrm{L}^{-1}\right)\end{array}$ & Jumlah ventilasi & & & & \\
\hline \multirow[t]{2}{*}{5} & 1 & $44.0 \mathrm{a}$ & $224.2 \mathrm{a}$ & $20036.7 \mathrm{c}$ & $25.3 \mathrm{a}$ \\
\hline & 2 & $38.0 \mathrm{a}$ & $193.6 \mathrm{a}$ & $19821.8 \mathrm{~d}$ & $29.0 \mathrm{a}$ \\
\hline \multirow[t]{2}{*}{10} & 1 & $32.0 \mathrm{~b}$ & $163.1 \mathrm{~b}$ & $22568.7 \mathrm{c}$ & $23.0 \mathrm{~b}$ \\
\hline & 2 & $34.7 \mathrm{~b}$ & $176.6 \mathrm{~b}$ & 20159.2 c & $28.3 \mathrm{a}$ \\
\hline \multirow[t]{2}{*}{15} & 1 & $32.0 \mathrm{~b}$ & $163.1 \mathrm{~b}$ & $23486.8 \mathrm{~b}$ & $21.0 \mathrm{~d}$ \\
\hline & 2 & $34.3 \mathrm{~b}$ & $174.9 \mathrm{~b}$ & $21982.3 \mathrm{~b}$ & $25.0 \mathrm{~b}$ \\
\hline \multirow[t]{2}{*}{20} & 1 & $30.0 \mathrm{c}$ & $152.8 \mathrm{c}$ & $23572.8 \mathrm{~b}$ & $22.0 \mathrm{c}$ \\
\hline & 2 & $32.0 \mathrm{c}$ & $163.1 \mathrm{c}$ & $22367.0 \mathrm{~b}$ & $23.0 \mathrm{c}$ \\
\hline \multirow[t]{2}{*}{25} & 1 & $29.0 \mathrm{c}$ & $147.8 \mathrm{c}$ & $22605.5 b$ & $20.7 \mathrm{~d}$ \\
\hline & 2 & $30.3 \mathrm{~d}$ & $154.6 \mathrm{~d}$ & $21717.8 \mathrm{~b}$ & $23.0 \mathrm{c}$ \\
\hline 30 & 0 & $27.7 \mathrm{e}$ & $140.9 \mathrm{e}$ & $42440.3 \mathrm{a}$ & $17.0 \mathrm{e}$ \\
\hline
\end{tabular}

Keterangan: Angka-angka yang diikuti huruf sama pada kolom yang sama tidak berbeda nyata pada uji DMRT taraf $\alpha$ 5\%

Pengurangan konsentrasi gula dan pemberian ventilasi pada tanaman in vitro memicu terjadinya proses fotosintesis sehingga sel akan berfungsi normal dan stomata akan menutup saat kekurangan air. Daun dari tunas pada perlakuan konsentrasi gula $5 \mathrm{~g} \mathrm{~L}^{-1}$ dengan ventilasi 2 (Gambar $2 \mathrm{~B}$ ) mempunyai diameter terkecil pada percobaan ini. Perlakuan konsentrasi gula $5 \mathrm{gL}^{-1}$ dengan ventilasi $1(\mathrm{~A})$, gula $10 \mathrm{~g} \mathrm{~L}^{-1}$ dengan ventilasi 1 (C) serta gula 10 $\mathrm{g} \mathrm{L}^{-1}$ dengan ventilasi 2 (D) tidak menyebabkan perbedaan pada diameter stomata. Kontrol (K) menyebabkan diameter terbesar. Hal ini mengindikasikan bahwa sel penjaga pada stomata dengan pengurangan konsentrasi gula dan pemberian ventilasi nyata menghasilkan sel penjaga yang lebih baik dibandingkan kontrol.

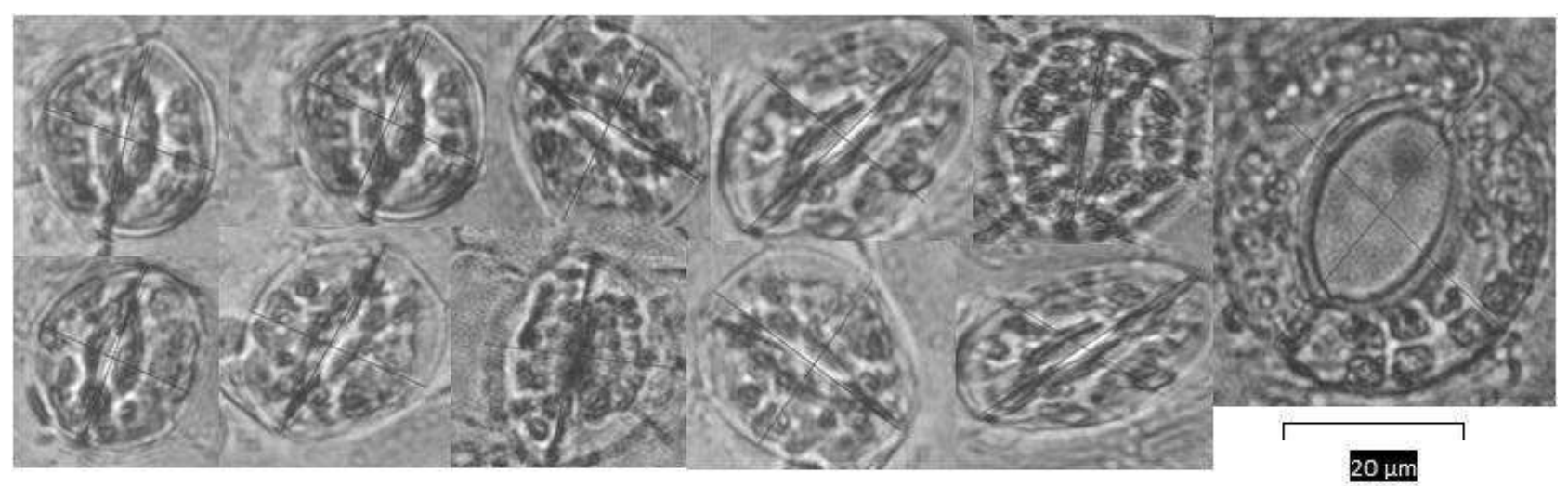

Gambar 2. Keragaan stomata tanaman kentang varietas Granola dengan teknik fotoautotrofik pada perlakuan konsentrasi gula $5 \mathrm{~g} \mathrm{~L}^{-1}(\mathrm{~A}, \mathrm{~B}) ; 10 \mathrm{~g} \mathrm{~L}^{-1}(\mathrm{C}, \mathrm{D}) ; 15 \mathrm{~g} \mathrm{~L}^{-1}(\mathrm{E}, \mathrm{F}) ; 20 \mathrm{~g} \mathrm{~L}^{-1}(\mathrm{G}, \mathrm{H}) ; 25 \mathrm{~g} \mathrm{~L}^{-1}$ (I,J) dengan ventilasi $1(\mathrm{~A}, \mathrm{C}, \mathrm{E}, \mathrm{G}, \mathrm{I})$; ventilasi $2(\mathrm{~B}, \mathrm{D}, \mathrm{F}, \mathrm{H}, \mathrm{J})$; kontrol $(\mathrm{K})$

Proses fotosintesis dapat berlangsung karena adanya kloroplas di dalam klorofil pada daun hijau. Klorofil sangat berperan bagi kelangsungan proses fotosintesis karena klorofil mampu menangkap cahaya matahari yang merupakan radiasi elektromaknetik pada spektrum kasat mata (Handoko dan Fajariyanti 2008). Tabel 8 menunjukkan bahwa pengurangan konsentrasi gula dan pemberian ventilasi menyebabkan daun menghasilkan jumlah kloroplas berbeda dan lebih tinggi jika dibandingkan dengan kontrol. Semakin rendah konsentrasi gula, kloroplas yang terlihat semakin banyak. Pada semua perlakuan konsentrasi gula, pemberian ventilasi 2 menghasilkan tunas dengan kandungan kloroplas daun lebih tinggi dibandingkan dengan ventilasi 1 . 
Tabel 9. Pengaruh konsentrasi gula dan ventilasi terhadap pertumbuhan planlet kentang varietas Granola percobaan 1 pada tahap aklimatisasi

\begin{tabular}{cccccccccccc}
\hline & \multicolumn{4}{c}{ Perlakuan } & \multicolumn{3}{c}{ Jumlah daun (helai) } & \multicolumn{3}{c}{ Jumlah buku (buah) } & \multicolumn{3}{c}{ Planlet hidup (\%) } \\
\hline \multicolumn{2}{c}{ Konsentrasi gula $\left(\mathrm{g} \mathrm{L}^{-1}\right)$} & Jumlah ventilasi0HSA & 5 HSA & 7 HSA & 0 HSA & 5 HSA & 7 HSA & 0HSA & 5 HSA & 7HSA \\
\hline 5 & 1 & 6.2 & - & - & 3.0 & - & - & 100 & 0 & 0 \\
10 & 2 & 5.2 & - & - & 2.3 & - & - & 100 & 0 & 0 \\
& 1 & 10.6 & - & - & 5.3 & - & - & 100 & 0 & 0 \\
15 & 2 & 10.4 & - & - & 5.4 & - & - & 100 & 0 & 0 \\
& 1 & 13.1 & - & - & 6.9 & - & - & 100 & 0 & 0 \\
20 & 2 & 12.0 & 5.0 & - & 6.3 & 2.5 & - & 100 & 13 & 0 \\
& 1 & 13.0 & - & - & 6.8 & - & - & 100 & 0 & 0 \\
25 & 2 & 13.2 & 10.0 & - & 7.0 & 5.0 & - & 80 & 13 & 0 \\
& 1 & 14.4 & 10.7 & 10.8 & 7.5 & 5.3 & 5.5 & 76 & 50 & 35 \\
30 & 2 & 15.0 & 11.2 & 11.8 & 7.2 & 5.6 & 5.9 & 100 & 67 & 67 \\
& 0 & 12.8 & 14.0 & - & 14.7 & 7.0 & - & 100 & 27 & 0 \\
\hline
\end{tabular}

Tabel 10. Pengaruh konsentrasi gula dan ventilasi terhadap pertumbuhan planlet kentang varietas Granola percobaan 2 pada tahap aklimatisasi

\begin{tabular}{ccccccccccc}
\hline & Perlakuan & \multicolumn{4}{c}{ Jumlah daun (helai) } & \multicolumn{3}{c}{ Jumlah buku (buah) } & \multicolumn{3}{c}{ Planlet hidup (\%) } \\
\hline $\begin{array}{c}\text { Konsentrasi gula } \\
\left(\mathrm{g} \mathrm{L}^{-1}\right)\end{array}$ & Jumlah & 0 & 5 & 7 & 0 & 5 & 7 & 0 & 5 & 7 \\
\hline 5 & 1 & 4.1 & - & - & 2.1 & - & - & 100 & 0 & 0 \\
& 2 & 4.0 & - & - & 2.1 & - & - & 100 & 0 & 0 \\
10 & 1 & 5.1 & - & - & 2.8 & - & - & 80 & 0 & 0 \\
& 2 & 4.1 & - & - & 2.1 & - & - & 100 & 0 & 0 \\
15 & 1 & 7.1 & - & - & 3.9 & - & - & 100 & 0 & 0 \\
& 2 & 4.4 & - & - & 2.1 & - & - & 80 & 0 & 0 \\
20 & 1 & 5.3 & - & - & 2.9 & - & - & 90 & 0 & 0 \\
& 2 & 5.0 & - & - & 2.7 & - & - & 60 & 0 & 0 \\
25 & 1 & 10.0 & - & - & 5.2 & - & - & 80 & 0 & 0 \\
& 2 & 9.8 & - & - & 5.2 & - & - & 100 & 0 & 0 \\
30 & 0 & 14.7 & 14.7 & - & 7.7 & 7.3 & - & 100 & 46.7 & 0 \\
\hline
\end{tabular}

Menurut Kozai et al. (2005) pada mikropropagasi konvensional $100 \%$ bibit mati saat aklimatisasi, sehingga kultur in vitro dianggap tidak efisien pada produksi bibit skala besar karena biayanya mahal. Pada percobaan 1 (Tabel 9), planlet yang mampu bertahan hingga 7 HSA adalah planlet yang ditumbuhkan pada media dengan perlakuan konsentrasi gula $25 \mathrm{gL}^{-1}$ dengan ventilasi 1 serta gula $25 \mathrm{gL}^{-1}$ dengan ventilasi 2. Persentase planlet hidup perlakuan konsentrasi gula $25 \mathrm{gL}^{-1}$ dengan ventilasi 2 lebih tinggi bila dibandingkan dengan gula $25 \mathrm{gL}^{-1}$ dengan ventilasi 1 . Pada percobaan 2 tidak terdapat percobaan yang dapat bertahan saat aklimatisasi (Tabel 10).

\section{KESIMPULAN}

Buku tunas dari kentang varietas Granola yang digunakan sebagai eksplan pada percobaan 1 menunjukkan bahwa peningkatan konsentrasi gula nyata meningkatkan jumlah daun dan jumlah buku. Pengurangan konsentrasi gula menyebabkan peningkatan kerapatan stomata dan jumlah kloroplas serta menyebabkan menyempitnya diameter stomata pada daun. Pemberian ventilasi pada botol kultur nyata menyebabkan peningkatan jumlah daun, jumlah buku, kerapatan stomata dan jumlah kloroplas serta menyempitnya diameter stomata. Interaksi konsentrasi gula dengan ventilasi hanya nyata meningkatkan kerapatan stomata, jumlah kloroplas dan menyebabkan penyempitan diameter stomata pada daun. Pengurangan konsentrasi gula dan pemberian ventilasi tidak mempengaruhi persentase eksplan hidup dan persentase kontaminasi pada semua perlakuan. Akar muncul pada tunas saat 2-3 MST. Planlet yang ditumbuhkan pada media dengan perlakuan konsentrasi gula $25 \mathrm{~g} \mathrm{~L}^{-1}$ dengan ventilasi 1 serta gula $25 \mathrm{~g} \mathrm{~L}^{-1}$ dengan ventilasi 2 mampu bertahan pada tahap aklimatisasi dan diduga dapat digunakan untuk produksi bibit

Pengurangan konsentrasi gula pada percobaan dengan eksplan pucuk nyata menyebabkan menurunnya jumlah daun dan buku yang terbentuk pada tunas, meningkatkan kerapatan stomata dan jumlah kloroplas serta menyebabkan penyempitan pada kloroplas daun. Penambahan ventilasi pada botol kultur nyata meningkatkan jumlah kloroplas dan menyebabkan 
penyempitan diameter pada stomata. Interaksi pengurangan konsentrasi gula dengan penambahan ventilasi pada semua perlakuan nyata meningkatkan kerapatan stomata dan jumlah kloroplas serta menyebabkan penyempitan pada diameter stomata. Konsentrasi gula dan pemberian ventilasi tidak mempengaruhi persentase eksplan hidup dan persentase kontaminasi pada semua perlakuan. Pada percobaan 2 tidak terdapat planlet yang mampu bertahan pada tahap aklimatisasi.

\section{DAFTAR PUSTAKA}

[BPS] Badan Pusat Statistik. 2013. Luas Panen, Produksi dan Produktivitas Kentang. Jakarta (ID): BPS.

Campbell. 2004. Biologi Edisi Kelima Jilid III. Jakarta (ID): Erlangga.

Handoko P dan Fajariyanti Y. 2008. Pengaruh spektrum cahaya tampak terhadap laju fotosintesis tanaman air Hydrilla verticillata. Seminar Nasional $X$ Pendidikan Biologi, FKIP, Universitas Nusantara PGRI Kediri ; 2006 Jul 21-22; Kediri, Indonesia. Kediri (ID): UNS Press. hlm 123.

Hidayat IM. 1991. Kemungkinan aplikasi teknik kultur jaringan dalam produksi bibit tanaman hortikultura. Dukungan sektor perbenihan dalam menunjang agroindustri hortikultura. Prosiding seminar sehari, Festival tanaman. [Waktu dan tempat pertemuan tidak diketahui]. Bogor(ID): IPB Press. hlm 31-44.
Kozai T. 1992. Effect of the difference between photoperiod and darkperiod temperatures, and photosynthetic photon flux density on the shot length and growth of potato planlets in vitro. J Japan Soc Hort Sci. 6 (1): 93-98.

Kozai T, Xiao Y, Nguyen QT, Afreen F, Zobayed SMA. 2005. Photoautothropic (sugar-free medium) micropropagation systems for large scale commercialization. Propagation of Ornamental Plants. 5(1): 23-24.

Kubota C. 2002. Photoautotrophic Micropropagation: Importance of Controlled Environment in Plant Tissue Culture.Combined Proceedings International Plant Propagators' Society. 52. 609-613.

Pertamawati. 2010. Pengaruh fotosintesis terhadap pertumbuhan tanaman kentang (Solanum tuberosum L.) dalam lingkungan fotoautotrof secara in vitro. Jurnal Sains dan Teknologi Indonesia. 12(1): 31-37.

Purwito A, Wattimena GA. 2008. Kombinasi persilangan dan seleksi in vitro untuk mendapatkan kultivar unggul kentang. Jurnal Ilmu Pertanian Indonesia. 13 (3):140-149.

Rukmana R. 2007. Budidaya dan Pasca Panen Tanaman Kentang. Yogyakarta(ID): Kanisius.

Xiao Y, Kozai T. 2006. In vitro multiplication of statice plantlets using sugar-free media. Scientia Horticulturae. 109 (1): 71-77. 